\title{
Influence of Feed Speed on the Content of Fine Dust during Cutting of Two-Side- Laminated Particleboards
}

\section{Utjecaj posmične brzine na nastajanje fine prašine tijekom piljenja ploča iverica obostrano obloženih laminatom}

\author{
Original scientific paper • Izvorni znanstveni rad \\ Received-prispjelo: 13. 5. 2014. \\ Accepted-prihvaćeno: 29. 1. 2016. \\ UDK: $630 * 839.811 ; 630 * 863.216$ \\ doi:10.5552/drind.2016.1417
}

\begin{abstract}
This paper deals with the problems of wood dust production during the sawing of two-side-laminated particleboards. It points out the dangerous impact of wood dust particles on people's health and other unfavourable influences in the working environment. The aim of the paper was to introduce the research of dustiness, to determine the content of fine particles in sawdust and analyse the influence of feed rate on the granularity of sawdust created in the process of sawing two-side-laminated particleboards using modern circular saw. Sawing parameters were chosen for the optimal cutting speed of the circular-saw blade Pilana TFZL, $v_{c}=84.3 \mathrm{~m} \cdot \mathrm{s}^{-1}$ and for three feed rates of a workpiece with the cut $v_{f}=10,15,20 \mathrm{~m} \cdot \mathrm{min}^{-1}$. The collected sawdust particles were subjected to the particle-size analysis under exactly defined conditions by sieving and the basic granulometric analysis was made. Sieve analysis gives only a general particle-size distribution without any information considering the mass concentration of fine fraction of dust. Therefore, laser particle sizer Analysette 22 Microtec Plus was used to specify details concerning the size of dust particles smaller than $63 \mu \mathrm{m}$, which were collected in the bottom collector.
\end{abstract}

Key words: wood dust, particle-size distribution, circular saw blade, two-side-laminated particleboard

SAŽETAK • U radu se analiziraju problemi nastajanja drvne prašine tijekom piljenje ploča iverica obostrano obloženih laminatom. Upozorava se na štetan utjecaj čestica drvne prašine na zdravlje ljudi i na druge nepovoljne utjecaje u radnoj okolini." Cilj rada bio je predstaviti istraživanja o onečišćenju radnog prostora drvnom prašinom, odrediti sadržaj sitnih čestica u piljevini te analizirati utjecaj posmične brzine na granulometrijski sastav piljevine nastale tijekom piljenja ploča iverica obostrano obloženih laminatom na suvremenoj kružnoj pili. Parametri piljenja izabrani su za optimalnu brzinu rezanja lista kružne pile Pilana TFL, $v_{c}=84,3 \mathrm{~m} \cdot \mathrm{s}^{-1}$, i za tri posmične brzine obratka $v_{f}=10,15$ i $20 \mathrm{~m} \cdot \mathrm{min}^{-1}$. Analizirane su veličine čestica piljevine pri točno određenim uvjetima prosijavanja te je određen granulometrijski sastav piljevine. Analiza piljevine prosijavanjem daje samo opću raspodjelu veličina čestica, bez informacije o masenoj koncentraciji frakcija fine drvne prašine. Stoga je za detaljnije određivanje veličina čestica drvne prašine manjih od $63 \mu \mathrm{m}$ koje su prikupljene u kolektoru na dnu sita primjenjen laserski uređaj Analysette 22 Microtec Plus.

Ključne riječi: drvna prašina, raspodjela veličine čestica, kružna pila, iverica obostrano obložena laminatom

\footnotetext{
${ }^{1}$ Authors are PhD student and assitant professor at Faculty of Forestry and Wood Technology, Mendel University in Brno, Czech Republic. ${ }^{2}$ Author is an assitant professor at Faculty of Wood Technology, Poznań University of Life Sciences, Poland.

${ }^{1}$ Autori su doktorandica i docent Fakulteta šumarstva i drvne tehnologije, Mendelovo sveučilište u Brnu, Republika Češka. ${ }^{2}$ Autor je docent Fakulteta drvne tehnologije, Sveučilište bioloških znanosti u Poznanu, Poljska.
} 


\section{INTRODUCTION}

\section{UVOD}

Together with the main product, chip sawdust is also produced during wood machining. The shape, dimension and amount of sawdust particles depend on physical and mechanical properties of sawed wood as well as on the shape, dimensions, sharpness of the cutting blade and technical and technological conditions of the sawing process (Prokeš, 1978; Goglia, 1994; Lisičan, 1996; Dzurenda, 2007). The sawdust produced during wood machining also contains small dust particles, which, when dispersed in the air, can pose a serious health risk to woodworkers (Hubbard et al., 1996; BeljoLučić et al., 2011; Čavlović et al., 2013). In accordance with the current legislation, wood-working and furniture companies have the problem how to remove or at least reduce harmful factors in the working environment. Dusty environment and excessive noise are among the greatest factors adversely affecting the human health. From hygienic aspects, the term dust implies small particles of solid materials, which are dispersed in the atmosphere or deposited on various places in the workplace. Serious health problems are mainly met in cases when the source of dust occurs in badly ventilated spaces, where there is deposition and accumulation of wood dust. It results in a considerable concentration of wood dust in the atmosphere, which can cause serious health complications (Kopecký and Pernica, 2004). Wood dust is a known inducer of cancer in the nasal cavity and recent reviews have focused on this issue. A summary of investigations of wood dust and the risk of cancer can be found in Nylander and Dement (1993), where the authors state that operatives in the woodworking industry face a higher risk of developing nasal cancer, especially those working with machines that generate wood dust (Palmqvist and Gustafsson, 1999).

Wood dust is also associated with a variety of respiratory diseases including asthma, chronic bronchitis, nasal symptoms and eye symptoms, as well as chronic impairment in lung function (Carosso et al. 1987; Enarson and Chan-Yeung, 1990; Jacobsen et al., 2010).

There are only several reports about the dust generated during woodworking. Most of these reports are focused on dust of hardwood and softwood. There are even less papers dedicated to the creation of dust during the cutting of wood-based materials. For example, Chung et al. (2000) investigated the quantity, particle size distribution and morphology of dust created during the machining of MDF.

Particle boards are made by gluing wood particles together with some kind of resin. Therefore, machining, sanding or excessive heating of such composite material can cause decomposition releasing formaldehyde, carbon monoxide, hydrogen cyanide and phenol. The atmosphere pollution created by machining particle boards is an effect of dispersion of wood dust, which may act as a carrier of other chemicals contained in such boards, e.g. wood preservatives and wood adhesives that may themselves cause health effects if inhaled (Hursthouse et al., 2004). Therefore, special interest should be focused on fine dust created during cutting wood-based materials with the aim of preventing occupational diseases in woodworking industry.

The aim of this work was to determine the content of fine particles in sawdust created during sawing the particleboards by the modern circular saw at three levels of feed speed. The expected results may be the base of the preliminary evaluation of health risk related to dustiness.

\section{MATERIALS AND METHODS}

\section{MATERIJALI I METODE}

Experimental sawing was carried out at the Department of Forest and Timber Technology, Mendel University in Brno, on a modern experimental stand (Figure 1) intended for research of cutting by circular sawblades. This experimental equipment makes it possible to measure parameters of a cutting process, vibrations of circular sawblades and their noise.

For the research into dustiness, it was necessary to equip the stand with a sucking device (URBAN Technik, Libchavy, Czech Republic) and with a GTE (Gravimetric Techniques Emissions, TESO Praha, Czech Republic) for isokinetic sampling of dust. In researching dustiness, information is primarily obtained on the machine dust emission, which is the source of knowledge of the particle size composition of sawdust. Cutting conditions should be selected so that the machine dust emission can be expressed by a functional relationship to the removed chip thickness. Sampling of sawdust and dust is carried out isokinetically, i.e. under conditions of the total correspondence of the sampled air and air flowing inside the sucking device air channel. The actual air sampling approaches the isokinetic sampling most when it is carried out by a probe with optimum dimensions and shape and if the air speed in the sampling probe nozzle is identical (as for size and direction) with the speed of air in the place of measurement.

Sampling was carried out by an isokinetic gravimetric set GTE. The sucking device has to guarantee controllable air flow through the sampling device in order to ensure that conditions for isokinetic sampling are kept in every point of sampling. The period of sampling was determined on the basis of the number of points of sampling and in the measurement cross-section and by the period of sampling in one point. The period of sampling in every point of sampling has to be the same, usually five to ten minutes, but at least three minutes. The method of sampling has to be in accordance with the ČSN ISO 9096 standard.

In cutting, a standard circular sawblade Pilana TFZL (Pilana Saw Bodies s.r.o, Hulín, Czech Republic) was used for trimming boards to size, diameter 350 $\mathrm{mm}$, number of teeth 108 (geometry $\alpha=18^{\circ}, \beta=66^{\circ}, \gamma$ $=6^{\circ}$ ). Before the experiment, the radius of edge blunting, which did not exceed the value of $r_{0}=9 \mu \mathrm{m}$, was verified. Cutting parameters were set up for the optimum cutting speed $\left(v_{\mathrm{c}}=84.3 \mathrm{~m} \cdot \mathrm{s}^{-1}\right.$ and three feed rates of a workpiece with the cut $v_{\mathrm{f}}=10,15,20 \mathrm{~m} \cdot \mathrm{min}^{-1}$ ). 


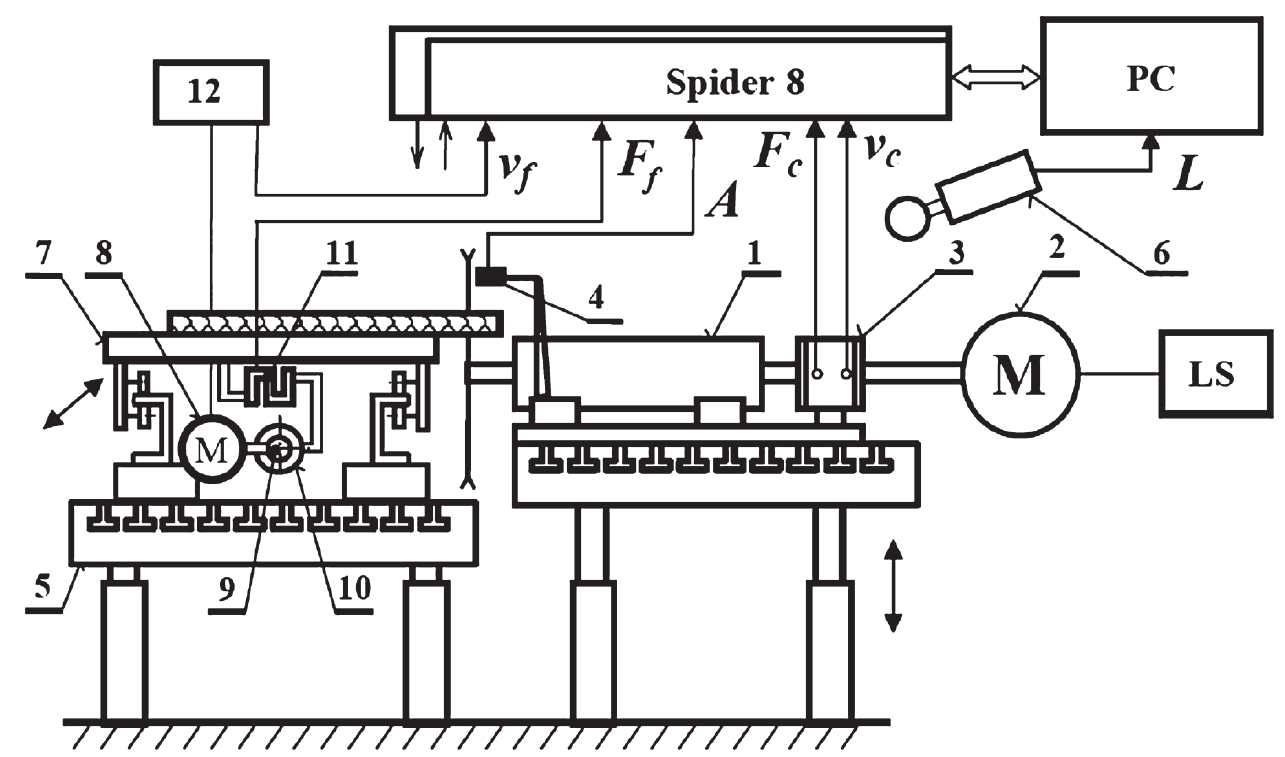

Figure 1 Schematic diagram of the experimental stand. 1 - spindle, 2 - electric motor with rpm control LS, 3 - sensor of cutting force $F_{\mathrm{c}}$ and speed $v_{\mathrm{c}}, 4$ - contactless sensor of vibrations A, 5 - grid table, 6 - noise meter, 7 - feed car, 8 - electric motor of car feed, 9 - ball screw, 10 - nut, 11 - feed force sensor $F_{\mathrm{f}}, 12$ - frequency converter for speed $v_{\mathrm{f}}$

Slika 1. Shematski dijagram eksperimenta: 1 - vratilo, 2 - elektromotor s kontrolom broja okretaja LS, 3 - senzor sile rezanja $F_{\mathrm{c}}$ i brzine $v_{\mathrm{c}}, 4$ - beskontaktni senzor vibracija A, 5 - rešetkasti stol, 6 - bukomjer, 7 - posmična naprava, 8 - elektromotor za pogon posmične naprave, 9 - kuglični vijak, 10 - matica, 11 - senzor posmične sile $F_{\mathrm{f}}, 12$ - frekvencijski pretvarač za posmičnu brzinu $v_{\mathrm{f}}$

Dustiness was evaluated for typical working conditions of circular saws. The measurement was made in trimming samples of two-side-laminated particleboards Duropal, which was produced by the company KRONOSPAN (Czech Republic). The density of rectangular prisms $(800 \times 350 \times 39 \mathrm{~mm})$ was $\rho=700 \mathrm{~kg} \cdot \mathrm{m}^{-3}$.

\subsection{Particle size analysis of sawdust}

\subsection{Analiza veličine čestica piljevine}

Under exactly defined conditions, the basic granulometric analyses were carried out at the Department of Furniture Design, Poznan University Life of Sciences, by sieving, which means by screaning of sampled dust on a set of sieves with mesh size of $0.5 \mathrm{~mm}, 0.25 \mathrm{~mm}, 0.125$ $\mathrm{mm}$ a $0.063 \mathrm{~mm}$ during the time $T=20 \mathrm{~min}$ on an automatic vibration sieving machine AS 200 (Retsch, Germany). The weights of fractions on sieves were subsequently weighed on the laboratory scales WPS 510/C/2 (Radwag, Poland) with a weighing accuracy of $0.001 \mathrm{~g}$.

Sieve analysis gives only a general particle-size distribution without any information considering the fine fractions of dust (Dzurenda and Orłowski, 2011). Therefore, laser particle sizer Analysette 22 Microtec Plus (Fritsch, Germany) was used to determine the size distribution of dust particles collected in the bottom collector, which was below the sieve with the mesh size of $0.063 \mathrm{~mm}$. This sizer automatically carries out a particle size measurement according to predetermined SOP (Standard Operating Procedure) and theoretical assumptions. The obtained results were processed by the MaScontrol (Fritsch, Germany) software in order to generate the particle-size distribution curves of the tested dust samples. It gives two types of quantities:

- the sum of the distribution $Q_{\mathrm{r}}$

- the density of the distribution $q_{\mathrm{r}}$
The curve of the distribution sum $Q_{\mathrm{r}}(x)$ shows a standardized total quantity of all particles with equivalent diameters less than or equal to $x$. Each point along the curve of the distribution sum represents the sum of the quantity components of all particles. The curve of the density distribution $q_{\mathrm{r}}(x)$ is the first derivative of $Q_{\mathrm{r}}(x)$ by $x$. It frequently appears in the bell shape.

In agreement with $d Q_{\mathrm{r}}(x)=q_{\mathrm{r}}(X) d x, q_{\mathrm{r}}(x)$ is the component of a quantity $d Q_{\mathrm{r}}(X)$, which is contained in the interval $\mathrm{dx}$ for particles from $x$ and $x+d x$. The result is a random quantity $r$, where:

$$
q_{r}(x)=\frac{x^{r} \cdot q_{r}(x)}{\sum_{1=1}^{n} x_{i}^{r} \cdot q_{O i}\left(x_{i}\right)}=\frac{d Q_{r}(x)}{d x}
$$

The fractions of dust in the range $<2.5 \mu \mathrm{m}, 2.5-4$ $\mu \mathrm{m}$ and further are obtained based on particle size distribution curves generated during the measurements. The mass of the dust particles collected in the bottom collector, under the sieve with the smallest mesh, had to be taken in subsequent calculations to determine the content of particles with these dimensions in the total mass of dust created during the machining due to the fact that these fractions referred to the samples separated by the sieve analysis. Therefore, the final result of the particlesize measurements of the smallest particles in the dust was the product of the fraction $<63 \mu \mathrm{m}$ and the fractions calculated in applied ranges.

\section{RESULTS AND DISCUSSION}

\section{REZULTATI I RASPRAVA}

According to the sieve analyses - granulometric composition of dry sawdust, histograms (Figure 2) of the distribution of particular particle fractions for the 

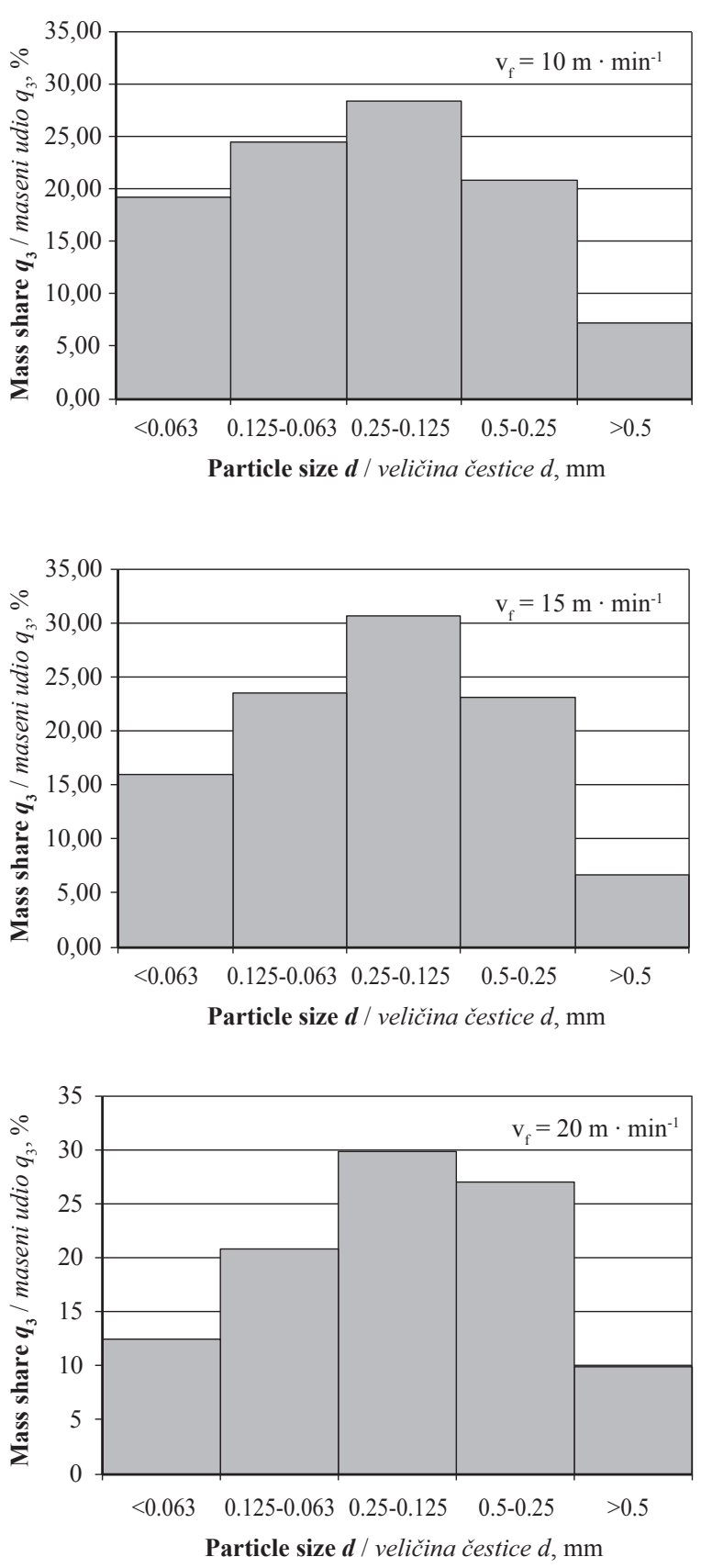

Figure 2 Histograms of sawdust particle-size distribution Slika 2. Histogrami raspodjele veličina čestica piljevine

feed speed $v_{\mathrm{f}}=10 \mathrm{~m} \cdot \mathrm{min}^{-1}, 15 \mathrm{~m} \cdot \mathrm{min}^{-1}$ and 20 $\mathrm{m} \cdot \mathrm{min}^{-1}$ were generated. The highest gravimetric proportion occurs in the range from 0.125 to $0.250 \mathrm{~mm}$. There is a relatively high percentage of particles smaller than $0.063 \mathrm{~mm}$, which include potentially airborne particles and from the aspect of occupational health and safety, they can be the most dangerous for workers in the working environment. Substantial increase of the occurrence of these particles in the sawdust was noted with the decreasing feed speed.

Figure 3 shows the cumulative distribution of particle size of the analysed sawdust. It can be concluded that the dust created during cutting at feed speed of $10 \mathrm{~m} \cdot \mathrm{min}^{-1}$ is finer than during machining at feed speed of 15 or $20 \mathrm{~m} \cdot \mathrm{min}^{-1}$. This result was expected due to a well-known fact that the amount of fine sawdust significantly increases with the decreasing feed speed - chip

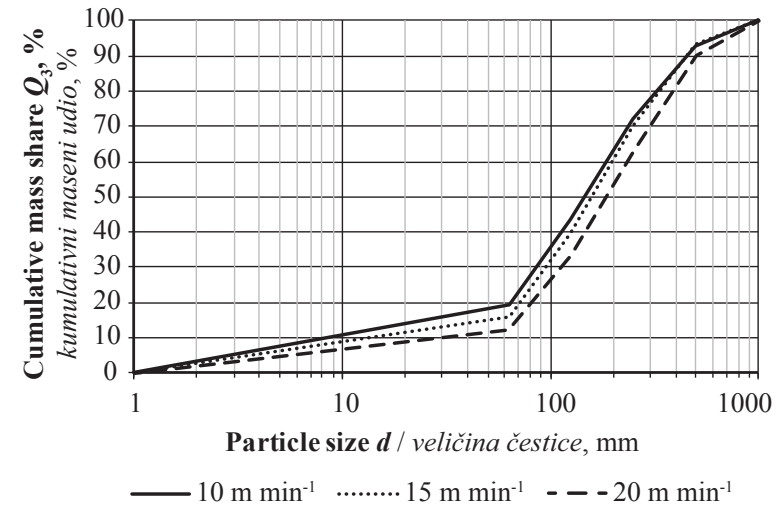

Figure 3 Cumulative particle-size distribution

Slika 3. Kumulativna raspodjela veličina čestica

thickness (Barcík and Gašparík, 2014; Dzurenda et al., 2010). Hemmilä et al. (2003) stated that decreasing feed speed causes decreasing of airborne dust emission but this is quite the opposite of the statement that increasing of chip thickness decreases airborne dust emission. Palmqvist and Gustasson (1999) came to the conclusion that the most important factor for the amount of wood dust created from machining of different materials is the average chip thickness.

The effect of cutting parameters on particle distribution of chipped wood during cutting along the grain when the working table is in upper position with higher contact angle of teeth and cutting material is not quite clear because of complex and varying morphology of the processed material, which ranges from softwood through light and dense hardwoods to particleboards, and differences in fragmentation of chips generated during sawing (Beljo Lučić et al., 2007).

Figure 4, 5 and 6 show the results of the analysis of dust sampled from the bottom collector of the sieving machine, which were generated by MaScontrol software in analysing the measuring data from the particle sizer. The graphs show the cumulative and discrete particle-size distribution of analysed dust. These results indicate that the content of fine particles in the tested dust created during cutting at the feed speed $v_{\mathrm{f}}=10 \mathrm{~m} \cdot \mathrm{min}^{-1}$ is higher than when other speed values are used. Particle-size distribution obtained by the particle measurement method with laser diffraction gives a different range of the most numerous particles. It can be seen that the dust particles with the size below $63 \mu \mathrm{m}$ account for less than $50-75 \%$ of the total material analyzed. This demonstrates the inaccuracy of both methods, which is caused due to the specific shape of wood dust particles. Their length is usually larger than the other dimensions, therefore the wood dust particles pass through a sieve mesh of smaller size than their length.

Figure 7 demonstrates the total contents of particles with assumed critical size limits of 2.5, 4 and 10 $\mu \mathrm{m}$ in the tested sawdust, which were calculated on the basis of the particle-size distribution obtained by the laser diffraction method and taking into account the mass share of the fraction $<63 \mu \mathrm{m}$ determined by the sieving method. It is easy to see that the largest share of fine dust is generated at feed speed $v_{\mathrm{f}}=10 \mathrm{~m} \cdot \mathrm{min}^{-1}$ and 


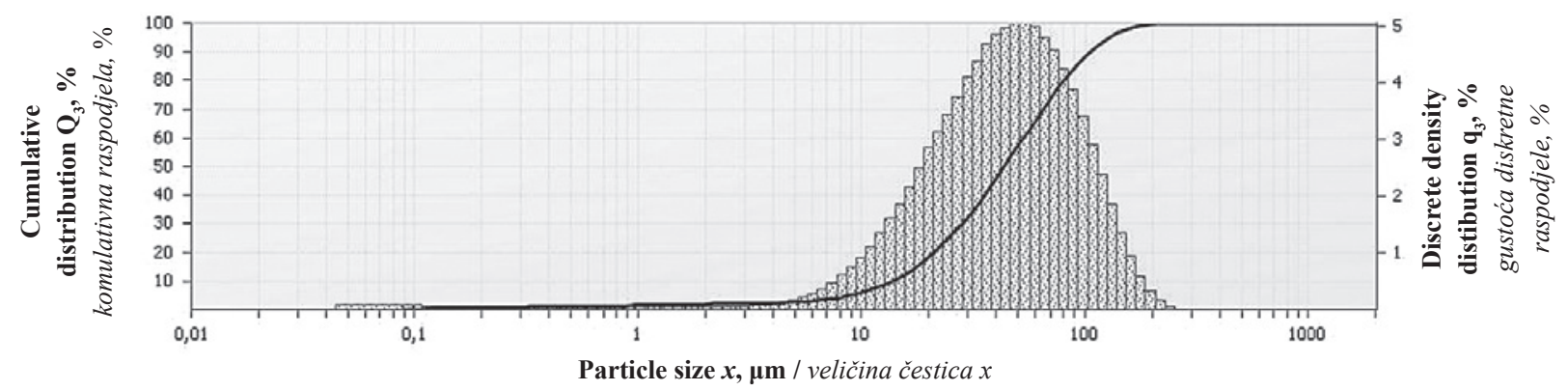

Figure 4 Particle size distribution of dust created during sawing at feed speed $v_{\mathrm{f}}=10 \mathrm{~m} \cdot \mathrm{min}^{-1}$ obtained by laser particle measurement

Slika 4. Raspodjela veličina čestica drvne prašine nastale tijekom piljenja iverice pri posmičnoj brzini $v_{\mathrm{f}}=10 \mathrm{~m} \cdot \mathrm{min}^{-1}$ dobivena laserskim mjerenjem čestica

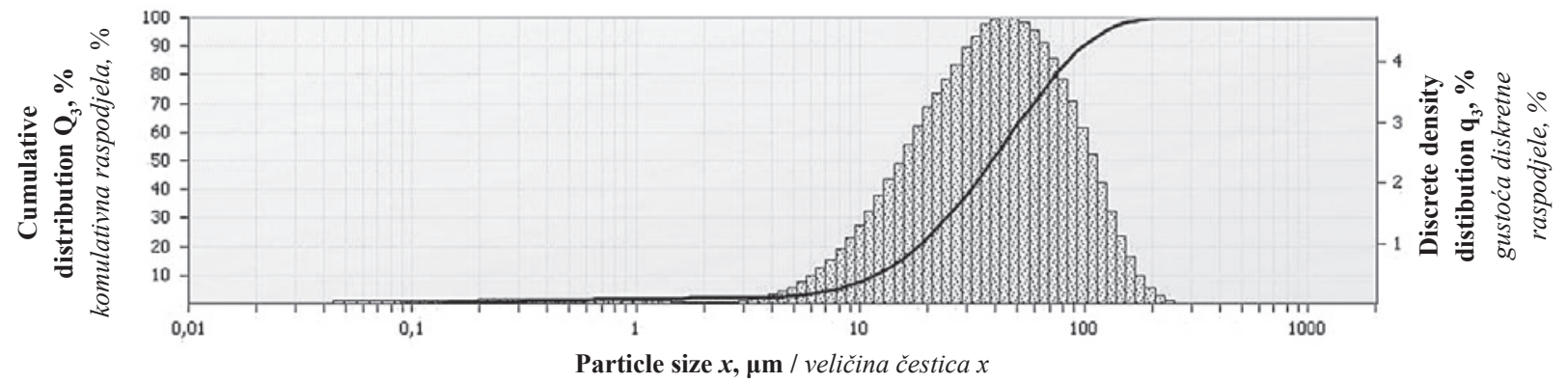

Figure 5 Particle size distribution of dust created during sawing at feed speed $v_{\mathrm{f}}=15 \mathrm{~m} \cdot \mathrm{min}^{-1}$ obtained by laser particle measurement

Slika 5. Raspodjela veličina čestica drvne prašine nastale tijekom piljenja iverice pri posmičnoj brzini $v_{\mathrm{f}}=15 \mathrm{~m} \cdot \mathrm{min}^{-1}$ dobivena laserskim mjerenjem čestica

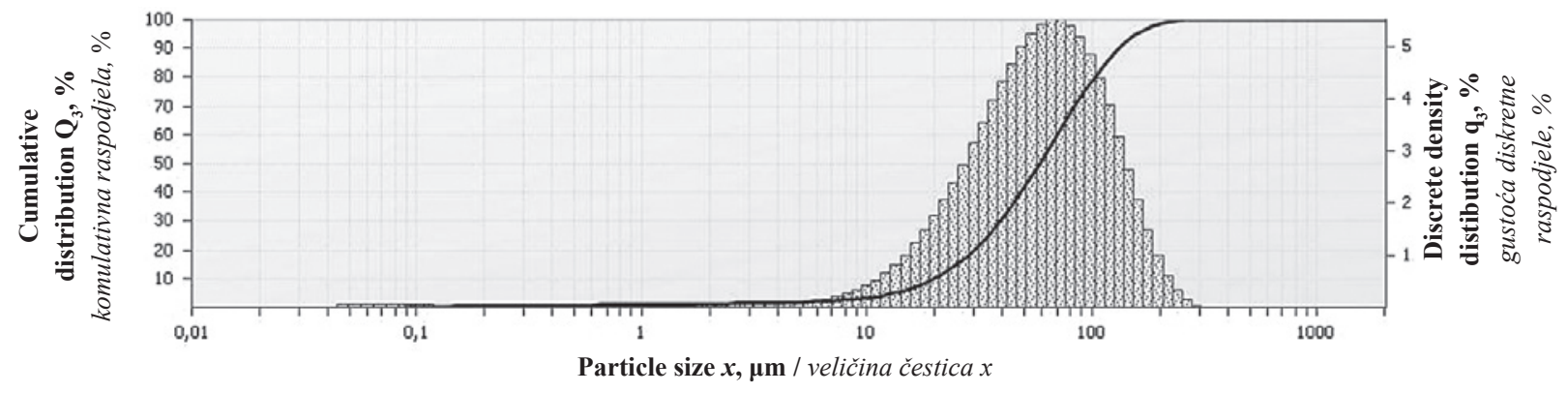

Figure 6 Particle size distribution of dust created during sawing at feed speed $v_{\mathrm{f}}=20 \mathrm{~m} \cdot \mathrm{min}^{-1}$ obtained by laser particle measurement

Slika 6. Raspodjela veličina čestica drvne prašine nastale tijekom piljenja iverice pri posmičnoj brzini $v_{\mathrm{f}}=20 \mathrm{~m} \cdot \mathrm{min}^{-1}$ dobivena laserskim mjerenjem čestica

that the amount of this dust increases with the decreasing feed speed.

The calculated rates of the smallest particles are shown in Table 1. The level of the occupational hazard on a given machining station caused by wood dust can be primitively estimated based on the comparison of the measured values.

It should be noted that the content of the particles with the size lower than $10 \mu \mathrm{m}$ is only about $1 \%$ in the total dust for the feed speed $v_{\mathrm{f}}=10$ and $15 \mathrm{~m} \cdot \mathrm{min}^{-1}$ and about $0.5 \%$ for the feed speed $v_{\mathrm{f}}=20 \mathrm{~m} \cdot \mathrm{min}^{-1}$. This is generally negligible but during machining a large amount of dust can be created and it might pollute a huge volume of the air at the acceptable limit of dust concentration. These particles, when dispersed in surrounding air of the working place, are potentially re-

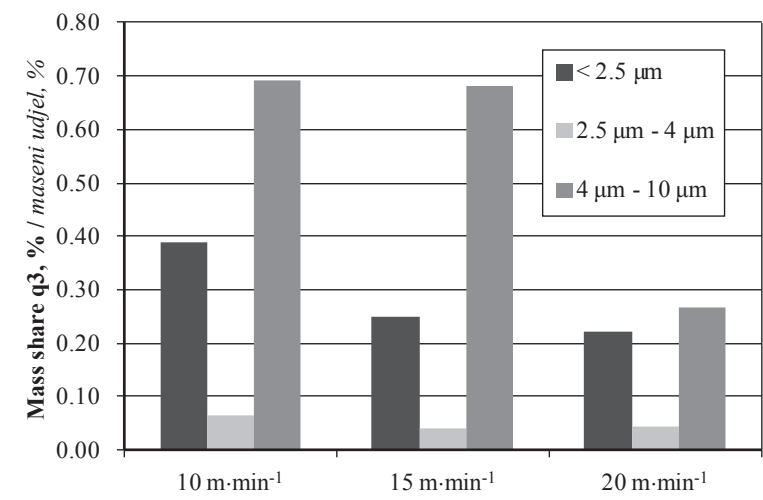

Figure 7 Mass share of fine particles for three feed speeds $(10,15,20 \mathrm{~m} / \mathrm{min})$

Slika 7. Maseni udjel finih drvnih čestica za tri posmične brzine $(10,15,20 \mathrm{~m} / \mathrm{min})$ 
Table 1 Mass rate of the smallest particles

Tablica 1. Maseni udjel najsitnijih čestica

\begin{tabular}{|c|c|c|c|c|c|c|}
\hline $\begin{array}{c}\text { Upper limit } \\
\begin{array}{c}\text { Gornja granica } \\
\mu \mathrm{m}\end{array}\end{array}$ & \multicolumn{2}{|c|}{$\begin{array}{c}\text { Mass rate in the smallest sieving fraction } \\
\text { Maseni udjel u frakciji najsitnijih čestica } \\
\%\end{array}$} & \multicolumn{3}{c|}{$\begin{array}{c}\text { Mass rate in the total dust } \\
\text { Maseni udjel u ukupnoj drvnoj prašini } \\
\%\end{array}$} \\
\hline & $10 \mathrm{~m} \cdot \mathrm{min}^{-1}$ & $15 \mathrm{~m} \cdot \mathrm{min}^{-1}$ & $20 \mathrm{~m} \cdot \mathrm{min}^{-1}$ & $10 \mathrm{~m} \cdot \mathrm{min}^{-1}$ & $15 \mathrm{~m} \cdot \mathrm{min}^{-1}$ & $20 \mathrm{~m} \cdot \mathrm{min}^{-1}$ \\
\hline 2.5 & 2.03 & 2.01 & 1.38 & 0.389 & 0.250 & 0.220 \\
\hline 4 & 2.36 & 2.33 & 1.65 & 0.454 & 0.289 & 0.263 \\
\hline 10 & 5.96 & 7.79 & 3.31 & 1.145 & 0.969 & 0.529 \\
\hline 20 & 18.56 & 23.40 & 10.20 & 3.564 & 2.913 & 1.628 \\
\hline 30 & 32.79 & 38.71 & 20.17 & 6.295 & 4.818 & 3.221 \\
\hline 40 & 45.94 & 51.82 & 31.15 & 8.821 & 6.450 & 4.973 \\
\hline 50 & 57.14 & 62.46 & 41.77 & 10.972 & 7.775 & 6.670 \\
\hline 63 & 68.85 & 73.19 & 54.18 & 13.220 & 9.110 & 8.650 \\
\hline
\end{tabular}

sponsible for the risk of occupational diseases. Its value is up to $5 \mathrm{mg} \cdot \mathrm{m}^{-3}$ for agglomerated materials with phenol formaldehyde resin in the Czech Republic (ČSN ISO 481).

\section{CONCLUSION \\ 4. ZAKLJUČAK}

There are many methods for the determination of particle-size distribution, but due to the fact that wood dust particles are irregularly shaped, the measurement of particle size done by different methods may give various results. Determination of the content of fine particles in the dust created during working of wood and wood composites often requires simultaneous application of measurement techniques with different measuring ranges due to the large dimensional range of analyzed particles.

On the basis of findings and results obtained, it can be concluded that the rate of fine dust created when trimming to size of laminated particleboards significantly increases with the decreasing feed speed. This is generally valid for other types of cutting operations of woodbased materials because a secondary partition of wood mater occurs. So this increase is particularly caused by the structure of agglomerated material but also by the used tool. Teeth of circular saw blades for trimming tend to have rather small cutting angle. Small angles may cause generating chips that are very bent and prone to disintegration (Očkajová and Beljaková, 2004), which increases the proportion of fine dust particles.

Although, based on tests, a seemingly insignificant amount of dust of $10 \mu \mathrm{m}$ and smaller was found in the whole mass of the created sawdust, it can be assumed that in the process of sawing particleboards, there is a high risk of formation of dust particles harmful to the health of workers employed in woodworking stations. Even this relatively small amount of fine dust can cause the pollution of a huge volume of air in excess of the permitted level.

\section{Acknowledgement - Zahvala}

This paper was also supported by the European Social Fund and the state budget of the Czech Republic, project "The Establishment of an International Re- search Team for the Development of New Wood-based Materials" Reg. No. CZ.1.07/2.3.00/20.0269. The author thanks for the financial support for the projects.

\section{REFERENCES}

\section{LITERATURA}

1. Barcík, Š.; Gašparík, M., 2014: Effect of tool and milling parameters on the size distribution of splinters of planed native and thermally modified beech wood. BioResources, 9 (1): 1346-1360 http://dx.doi.org/10.15376/biores.9.1.1346-1360.

2. Beljo Lučić, R.; Čavlović, A.; Đukić, I., 2007: Factors influencing particle size distribution of oak and fir sawdust in circular sawing. Wood Research, 52 (1): 35-46.

3. Beljo Lučić, R., Čavlović, A. O.; Jug, M., 2011: Definitions and relation of airborne wood dust fractions. I4th international Scientific Conference - Woodworking Technique, Prague, 25-32.

4. Carosso, A.; Ruffino, C.; Bugiani, M., 1987: Respiratory diseases in wood workers. British Journal of Industrial Medicine, 44: 53-56 http://dx.doi.org/10.1136/oem.44.1.53.

5. Čavlović, A. O.; Beljo Lučić, R.; Jug, M.; Radmanović, K.; Bešlić, I., 2013: Side-by-side determination of workers' exposure to wood dust with IOM and open-faced samplers. Archives of Industrial Hygiene and Toxicology, 64: 379-384.

6. Dzurenda, L., 2007: Sypka drevna hmota, vzduchotechnická doprava a odlučovanie. (Bulk wood mass, air transport and separation). Zvolen: V-TU. $182 \mathrm{p}$.

7. Dzurenda, L.; Orlowski, K., 2011: The effect of thermal modification of ash wood on granularity and homogenity of sawdust in the sawing process on a sash gang saw PRW $15-\mathrm{M}$ in view of its technological usefulness. Wood Research Papers. Reports. Announcements 54(186), 27-37.

8. Dzurenda, L.; Orlowski, K.; Grzeskiewicz, M., 2010: Effect of Thermal Modification of Oak Wood on Sawdust Granularity. Drvna industrija, 61 (2): 89-94.

9. Enarson, D.; Chan-Yeung, M., 1990: Characterization of health effects of wood dust exposures. American Journal of Industrial Medicine, 17: 33-38 http://dx.doi.org/10.1002/ajim.4700170107.

10. Goglia, V., 1994: Strojevi i alati za obradu drva I. Zagreb: GRAFA. $235 \mathrm{p}$.

11. Hemillä, P.; Gottlöber, C.; Weeling, I., 2003: Effect of cutting parameters to dust and noise in wood cutting, laboratory and industrial tests. $16^{\text {th }}$ International Wood Machining Seminar. Matsue, Japan, 375-384.

12. Hubbard, R.; Lewis, S.; Richards, K.; Britton, J.; Johnston, I., 1996: Occupational exposure to metal or wood 
dust and aetiology of cryptogenic fibrosing alveolitis. Lancet, 347: 284-289

http://dx.doi.org/10.1016/S0140-6736(96)90465-1.

13. Hursthouse, A.; Allan, F.; Rowley, L.; Smith, F., 2004: A pilot study of personal exposure to respirable and inhalable dust during the sanding and sawing of medium density fibreboard (MDF) and soft wood, International Journal of Environmental Health Research, 14 (4): 323-326 http://dx.doi.org/10.1080/09603120410001725667.

14. Chung, K. Y. K.; Cuthbert, R. J.; Revell, G. S.; Wassel, S. G.; Summers, N., 2000: A Study on Dust Emission, Particle Size Distribution and Formaldehyde Concentration During Machining of Medium Density Fibreboard, The Annals of Occupational Hygiene, 44 (6): 455-466 http://dx.doi.org/10.1016/S0003-4878(00)00005-3.

15. Jacobsen, G.; Schaumburg, I.; Sigsgaard, T.; Schlünssen, V., 2010: Non-malignant respiratory diseases and occupational exposure to wood dust. Part 1. Fresh wood and mixed wood industry. Ann Agric Environ Med, 17: 15-28.

16. Kopecký, Z.; Pernica, J., 2004: Wood dust and health protection. Rocz. AR Poznań CCCLXVIII, Technol. Drewn., 40: 293-300.

17. Lisičan, J., 1996: Teoria a technika spracovania dreva. (Theory and engineering of processing of wood). Zvolen: Matcentrum. $626 \mathrm{p}$.

18. Nylander, L. A.; Dement, J. M., 1993: Carcinogenic effects of wood dust: Review and discussion. American Journal of Industrial Medicine, 24: 619-647 http://dx.doi.org/10.1002/ajim.4700240511.
19. Očkajová, A.; Beljaková, A., 2004: Motion of sanding mean versus granularity of sand wood dust. In: Trieskové a beztrieskové obrábanie dreva. Starý Smokovec 2004, 163-168.

20. Palmqvist, J.; Gustafsson, S. I., 1999: Emission of dust planning and milling of wood. Holz als Roh-und Werkstoff, 57: 164-170 http://dx.doi.org/10.1007/s001070050035.

21. Prokeš, S., 1978: Obrabeni dreva a novych hmot ze dreva (Processing of wood and new wood materials). Praha: SNTL. 583 p.

22. *** ČSN ISO 481 Ovzduší na pracovišti. Vymezení velikostních frakcí pro měření poletavého prachu (Workplace atmospheres. Size fraction definitions for measurement of airborne particles)

\section{Corresponding address:}

\section{Ing. LUĎKA HLÁSKOVÁ}

Department of Wood Processing

Faculty of Forestry and Wood Technology

Mendel University in Brno

Zemědělská 3

Brno, 613 00, CZECH REPUBLIC

e-mail: xhlaskov@mendelu.cz 